\title{
Human Resource Strategies in China
}


This page is intentionally left blank 


\section{Human Resource Strategies in China}

\section{Alma Whiteley}

Curtin University of Tecbnology, Australia

\section{Sara Cheung}

Hong Kong Institute of

Human Resource Management, Hong Kong

Zhang Shi Quan

International Technology and Economy Insttute, China 


\section{Published by}

World Scientific Publishing Co. Pte. Ltd.

P O Box 128, Farrer Road, Singapore 912805

USA office: Suite 1B, 1060 Main Street, River Edge, NJ 07661

UK office: 57 Shelton Street, Covent Garden, London WC2H 9HE

\section{British Library Cataloguing-in-Publication Data}

A catalogue record for this book is available from the British Library.

\section{HUMAN RESOURCE STRATEGIES IN CHINA}

Copyright $\odot 2000$ by World Scientific Publishing Co. Pte. Ltd.

All rights reserved. This book, or parts thereof, may not be reproduced in any form or by any means, electronic or mechanical, including photocopying, recording or any information storage and retrieval system now known or to be invented, without written permission from the Publisher.

For photocopying of material in this volume, please pay a copying fee through the Copyright Clearance Center, Inc., 222 Rosewood Drive, Danvers, MA 01923, USA. In this case permission to photocopy is not required from the publisher.

ISBN 981-02-3840-1

Printed in Singapore. 


\section{CONTENTS}

1. INTRODUCTION 1

Characteristics of the open door policy 3

One policy: Two systems, PRC and FIEs 5

Human resource management strategies and practices in foreign invested enterprises in the PRC: The 1996 study 12

$\begin{array}{ll}\text { The development of a new pattern of thinking } & 16\end{array}$

2. IDEOLOGY IN CONTEXT 25

Western ideology: The business inheritance 25

Chinese ideology $\quad 32$

The economic context $\quad 39$

Impacts of the open door policy in China 42

3. HUMAN RESOURCES IN THE CONTEXT OF BUSINESS STRATEGY

Human resources in the context of business strategy 55

Human resource management in the West $\quad 60$

Human resource management strategies and practices in foreign invested enterprises in the PRC: The 1997 study 67

Business strategy theory and concepts $\quad 68$

$\begin{array}{ll}\text { Business strategy findings } & 76\end{array}$

4. HUMAN RESOURCE STRATEGIES IN THE CHINESE CONTEXT $\quad 89$

Human resource strategies in the Chinese context $\quad 89$

Fundamental personnel management model $\quad 99$

Transition to the human resource management model 101

$\begin{array}{ll}\text { Sophisticated human resource management model } & 104\end{array}$

$\begin{array}{ll}\text { Human resource strategy findings } & 106\end{array}$

5. THE ROLE OF THE HR FUNCTION IN FOREIGN INVESTED ENTERPRISES

The role of the HR function in foreign invested enterprises 115

$\begin{array}{ll}\text { Human resource practices } & 118\end{array}$ 
6. THE GREATEST DIRECTNESS IS FLEXIBLE-COMPATIBLE PARADIGMS

Compatible paradigms: Complex adaptive systems and Chinese relational systems

Complex adaptive systems

Characteristics of CAS

175

Chinese relational system

The need for a catalyst

7. REFERENCES

185

INDEX 